\title{
Okul Öncesi ve Sınıf Öğretmenlerinin Çocuk Cinsel İstismarının Bildirimine Yönelik Tutumlarını Etkileyen Etmenlerin İncelenmesi
}

\section{Münevver Can Yaşar1 $\quad$ Ümit Ünsal Kaya ${ }^{2} \quad$ Nezahat Hamiden Karaca $^{3}$}

Type/Tür:

Research/Araştırma

Received/Geliş Tarihi: June 16/

16 Haziran 2020

Accepted/Kabul Tarihi:

December 12/ 12 Aralık 2020

Page numbers/Sayfa No: 715-737

Corresponding

Author/İletişimden Sorumlu

Yazar: nhamiden@gmail.com

\section{$\checkmark$ iThenticate}

This paper was checked for plagiarism using iThenticate during the preview process and before publication. / Bu çalışma ön inceleme sürecinde ve yayımlanmadan önce iThenticate yazılımı ile taranmıştır.

Copyright (C) 2017 by Cumhuriyet University, Faculty of Education. All rights reserved.

Öz

$\mathrm{Bu}$ araştırma, öğretmenlerin çocuk cinsel istismarının bildirimine yönelik tutumlarını etkileyen etmenlerin incelenmesi amacıyla yapılmıştır. Araştırmanın çalışma grubuna, 2019-2020 eğitim-öğretim yılında Afyonkarahisar merkez ilçelerinde Milli Eğitim Müdürlüğüne bağlı anaokulları ve ilkokullarda görev yapan 213 sınıf eğitimi ve 207 okul öncesi öğretmeni dahil edilmiştir. Araştırmada veri toplama aracı olarak, öğretmenlerin kişisel bilgilerini belirlemek amaciyla "Genel Bilgi Formu" ve öğretmenlerin çocuk cinsel istismarının bildirimine yönelik tutumlarını belirlemek amacıyla "Çocuk Cinsel İstismarının Bildirimine Yönelik Öğretmen Tutum Ölçeği" kullanılmıștır. "Çocuk Cinsel İstismarının Bildirimine Yönelik Tutum Ölçeği" den elde edilen veriler sonucunda; öğretmenlerin cinsiyetlerine, öğretmenlerin mezun oldukları programa, okul öncesi öğretmenlerin meslekteki kıdemlerine, öğretmenlerin çocuk ihmal ve istismarı konusunda eğitim alma durumuna, öğretmenlerin Milli Eğitim politikaları kapsamında çocuk ihmal ve istismarı şüphesi bildirim yükümlülüğü durumuna ve öğretmenlerin Çocuk Koruma Kanunu (ÇKK) hakkında bilgi sahibi olma durumuna göre anlamlı farkl1lıklar tespit edilmiştir.

Anahtar Kelimeler: Okul öncesi dönem, okul öncesi öğretmeni, cinsel istismar, bildirim, tutum

Suggested APA Citation/Önerilen APA Atıf Biçimi:

Yaşar Can. M., Kaya, Ü. Ü. \& Karaca, N. H. (2021). Okul öncesi ve sınıf öğretmenlerinin çocuk cinsel istismarının bildirimine yönelik tutumlarını etkileyen etmenlerin incelenmesi. Cumhuriyet International Journal of Education, 10(2), 715-737. http://dx.doi.org/10.30703/cije.753489

\footnotetext{
${ }^{1}$ Doç. Dr., Eğitim Fakültesi, Temel Eğitim Bölümü, İzmir/Türkiye Assoc. Prof Dr., Education Faculty, Department of Basic Education, İzmir/Turkey

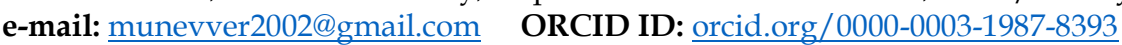

2 Öğr. Gör., Yabancı Diller YO, Yabancı Diller Bölümü, Afyonkarahisar/Türkiye Instructor, School of Foreign Languages, Department of Foreign Language, Afyonkarahisar/Türkiye e-mail: umitunsalkaya@gmail.com ORCID ID: orcid.org/0000-0001-7662-8089
}

3 Dr. Öğr. Üyesi, Eğitim Fakültesi, Temel Eğitim Bölümü, Afyonkarahisar/Türkiye Dr, Education Faculty, Department of Basic Education, Afyonkarahisar/Turkey e-mail: nhamiden@gmail.comＯRCID ID: orcid.org/0000-0002-7424-7669 


\title{
The Factors Affecting Preschool and Elementary Level Teachers' Attitudes Towards Reporting Child Sexual Abuse
}

\begin{abstract}
This study was conducted to investigate the factors that affect teachers' attitudes towards child sexual abuse reporting. The study group of the research included 213 elementary and 207 preschool teachers working at kindergartens and elementary schools affiliated to the Directorate of National Education in Afyonkarahisar city center during 2019-2020 academic year. In the research, "General Information Form" was used to collect the personal information of teachers and "Teacher Reporting Attitude Scale for Child Sexual Abuse" was used to determine teachers' attitudes towards reporting sexual abuse. The personal information of the teachers included in the study in the general information form were given in frequency and percentage distributions. In the analysis of the data obtained from the "Teacher Reporting Attitude Scale for Child Sexual Abuse"; Manny Whitney U Test was used for the variables of gender, graduated program, whether they have received any education related to child protection law and child sexual abuse, professional awareness of the responsibility of reporting possible child neglect and abuse regarding national education policies while Kruskall Wallis H Test was used for professional seniority. As a result of the data obtained from the "Teacher Reporting Attitude Scale for Child Sexual Abuse", significant differences were found out in the analysis of gender of the teachers, graduated program, the preschool teachers' seniority in the profession, professional awareness of the responsibility of reporting possible child neglect and abuse regarding national education policies, and teachers' knowledge of the child protection law.
\end{abstract}

Keywords: Early childhood, preschool teacher, child sexual abuse, reporting, attitude

\section{Giriş}

Çocuk cinsel istismarı, çocukların yaşamlarını fiziksel, psikolojik, sosyal ve gelişimsel olarak etkileyen evrensel bir gerçeklik ve çocuk haklarının en ağır ihlalidir. Bu gerçeklik içindeki olgular da öncelikle çocukların cinsel istismardan korunması ve istismar sonrası iyileştirme amacıyla aileye ve topluma yönelik etkili uygulamalar geliştirilmesi gereğini ortaya koymaktadır. Koruma ve önleme konusunda etkili uygulamalar için toplumsal farkındalık gerekmektedir. Bütüncül bir yaklaşımla toplumsal farkındalığın yaratılmasında, etkililik açısından erken çocukluk alanında çalışan öğretmenler (okul öncesi ve sınıf eğitimi öğretmenleri) ilk sırada yer almaktadır. Bu nedenle okul öncesi ve sınıf öğretmenlerinin çocukları cinsel istismardan koruma ve cinsel istismarı önleme konusunda gerekli bilgi ve becerilere sahip olması çocuğun bütünlüğü açısından yaşamsal önem taşımaktadır.

Çocuk cinsel istismarını Dünya Sağlık Örgütü/World Health OrganizationWHO (2017), "çocuğun tam olarak kavrayamadı̆̆ı, bilgilendirilmiş onamını veremediği, gelişimsel olarak hazır olmadığıı, yasaları ve sosyal tabuları ihlal eden cinsel davranışlara maruz kalması" olarak tanımlamaktadır. Buna göre bir çocuğu cinsel eylemlere teşvik etmek ya da zorlamak; yasadışı cinsel eylemlerde sömürmek, pornografik performans ve materyallerde kullanmak da tanım içine girmektedir (WamserNanney ve Campbell, 2020). Ayrica cinsel istismar, oral, anal ya da vajinal yollardan penetrasyon içeren cinsel temas ya da her türlü cinsel ilişki girişimini ve penetrasyon içermeyen genital dokunma ya da okşamayı da içerir (Hornor, 2010; Noble, Hartwig ve Shwayder, 2020). Erken çocukluk döneminde çocuklara yaşatılan bütün bu eylemler, çocukların yaşamlarını fiziksel, psikolojik, sosyal ve gelişimsel olarak 
olumsuz etkilemekte kısa ve uzun vadeli onarımı zor travmalara yol açmaktadır (Ayraler-Taner, Çetin, Işık ve İşeri, 2015; Bakır ve Kapucu, 2017). Bu çocuklar en çok da korku, öfke, üzüntü (Murali ve Prabhakar, 2018), kayg1, depresyon, panik bozukluğu (Draper vd., 2008; Haileye, 2013), saldırganlık, yeme bozukluğu, defansif kaçınma ve sosyal izolasyon, ileri yaşlarda cinsel davranış işlev bozukluğu ve intihar düşüncesi (American Psychological Association, 2014; Swea, Gordana ve Dragana, 2013) yaşamaktadırlar.

Çocuk cinsel istismarı, yaşları gereği, çocuk üzerinde belirli bir yetki, otorite veya sorumluluk taşıyan bir yetişkin veya yaşları ve gelişim aşamaları nedeniyle aralarında sorumluluk, güven ve güç ilişkisi farkı bulunan başka bir çocuk tarafından, çocuk üzerinde iktidar kurmak da dahil olmak üzere cinsel tatmin amacıyla gerçekleştirilmektedir (Olive, Collins ve Levitt, 2007; WHO, 2006). Bütün sosyoekonomik aile etmenleri ve yaş gruplarında, tüm ortamlarda gerçekleşebilen bu olgu; genelde yabancılar tarafından değil, çocuğun tanıdığı ve güven ilişkisi içinde olduğu erişkin yakınları tarafından işlenmektedir (Hornor, 2010; Lahtinen, Laitila, Korkman ve Ellonen, 2017; Modelli vd., 2012). Özellikle erken çocukluk dönemdeki çocuklar gelişimsel özellikleri göz önüne alındığında, istismara karşı daha savunmasız olmakta ve bunu ifade etmekte yetersiz kalmaktadır (Feng, Huang ve Wang, 2010). Çünkü cinsel içerikli oyunlar; yabancilardan korkma gibi davranışların yanında başarısızlık, sosyal izolasyon ve uyumsuzluk gibi davranış belirtilerini ortaya çıarabilir (Morrison, Bruce ve Wilson, 2018). Çocuklarla etkileşimde olan bireylerin, başka nedenlere de bağlanabilecek olan bu davranışsal göstergeleri istismar açısından değerlendirebilmesi güçleşir (Collin-Vezina, De La SablonniereGriffin, Palmer ve Milne, 2015; Kesner ve Robinson, 2002; Şahin, 2006; Yulaf ve Gümüştaş, 2013). Cinsel istismar mağduru çocuklar da güvendikleri suç faillerini kaybetme veya onlar tarafından cezalandırılma korkusu nedeniyle çoğu zaman bu durumu saklama eğilimi gösterir (Koçak ve Alpaslan, 2015). Bu boşluk çocukların suçluluk ve korku nedeniyle defalarca cinsel istismara maruz kalmasına neden olur (Alaggia, Collin-Vezina ve Lateef, 2017; Borg, Snowdon ve Hodes, 2014; WamserNanney ve Sager, 2018; McElvaney vd., 2020).

Cinsel istismar büyük oranda, aile ortamında ortaya çıkmakta ancak süreç içerisinde çocuğun gelişim ve eğitiminden sorumlu olan diğer ortamlarda da kendini göstermektedir (Can Yaşar vd., 2018). Bu nedenle çocukların ev ortamı dışında en çok zaman geçirdikleri yer olan okul ortamı, istismara uğrayan çocukların tespit edilmesi ve istismarın önlenmesi açısından büyük önem taşımaktadır. Burada öğretmenler devreye girmektedir.

Eğitim sürecinde neredeyse tüm gün çocuklarla birlikte olan ve onların özelliklerini iyi tanıyan öğretmenler, çocuklarda meydana gelebilecek davranış değişikliklerini tanıma ve tanımlama olanağına sahiptirler (Baginsky, 2003; CrossonTower, 2003; McKee ve Dillenburger, 2009; Yılmaz ve Cenkseven Önder, 2020). İlgili alanyazında yer alan araştırmalarda; öğretmenlerin çocuklarla sürekli bir arada olmaları ve çocuk gelişimi ile istismar hakkında bilgi ve deneyime sahip olmaları nedeniyle, aileleri tarafından herhangi bir kötü muameleye maruz kalan çocukların belirlenmesinde ve sonrasında korumaya alınmasında özel bir öneme sahip oldukları vurgulanmaktadır (Can Yaşar, İnal Kızıltepe ve Kandır, 2014; Ross ve Juarez, 2014; WHO, 2017). 
Bildirim (ihbar), bir suçun yetkili makamlar tarafından önlenmesi ve failin etkisiz hale getirilmesinin bir yoludur. Özellikle çocukların temel hak ve özgürlüklerinin kısıtlandığı durumlara tanıklık durumunda, işlenmekte olan suçu yetkili makamlara bildirme tüm bireylerin temel görevi olmalıdır. Dünyanın birçok ülkesinde olduğu gibi çocuk istismarını bildirim yükümlülüğü Türk Ceza Kanunu'nda da sabittir (m. 103, m. 104, m. 226, m. 227, m. 232). Kanunlara göre çocuğun fiziksel, cinsel veya duygusal yönden istismarının bildirim yükümlülüğü vardır. Halihazırda, işlenmekte olan herhangi bir suçu yetkili makamlara bildirmeyen kişi, bir yıla kadar hapis cezası ile cezalandırılır. Bu suçu kamu görevlisi veya sağlık mensubunun işlemesi halinde kendilerine daha ağır bir ceza verilir. Ayrıca bildirilmesi gereken suça ait mağdurun 15 yaşını bitirmemiş bir çocuk olması, suçu bildirmeme suçunun (Resmi Gazete, 2014) cezayı ağırlaştıran nitelikli hali olarak kabul edilmiştir. İhbar yükümlülüğü açısından öğretmenler, cinsel istismara uğramış çocuklar için potansiyel bir kurtarıcı olarak görülmelidir. İstismara uğrayan çocuklar için potansiyel bildirim kaynağı olmalarına rağmen, ne yazık ki öğretmenler hukuki sorumluluklarını ve yasalar uyarınca kendilerine sağlanan hak ve koruyucu maddeleri bilmiyorlarsa istismar şüphesini bildirmeyebilirler (Wurtele ve Schmitt, 1992). Günümüzde de her ne kadar hizmet öncesi veya hizmet sonrası eğitimlerde bu hukuki sorumluluklar öğretmenlere aktarılsa da bildirim hususunda tereddütlerin yaşandı̆̆ını gözlemlenmektedir (Akgül, 2015).

Görüldüğü gibi kanun ve yasalara göre öğretmenler, çocuk ihmal ve istismarı şüphesini ilgili makamlara bildirmekle yükümlüdür. Bu bildirim hem çocukların istismardan kurtulmasını ve tedavisini, hem de istismarcının cezalandırılmasını sağlar. Buna karşın resmî makamlarca kayda geçen istismar olgularının pek azının öğretmenler tarafından bildirildiği vurgulanmaktadır (Kenny, 2001). Şahin ve Beyazova (2001) ile Lynn (2008) bunun nedenlerini, öğretmenlerin bu tür olayları kime ve nasıl bildireceklerini bilememeleri, bildirmenin yararlı olacağına inanmamaları, dikkate alınmayacaklarından korkmaları, sonuçlarından çekinmeleri, istismarın ne olduğu hakkında yeteri bilgiye sahip olmamaları, çok ağır olmayan durumlarda da fiziksel istismarın ailede çocuğu disipline etmek için kullanılabilecek uygun bir yöntem olduğuna inanmaları ve aile içi ilişkilere karışmak istememeleri olarak siralamaktadir.

Alanyazın incelendiğinde; öğretmenlerin ve öğretmen adaylarının çocuk istismarı belirtilerini tanımlama ve nereye bildirmeleri gerektiği ile ilgili yeterli bilgiye sahip olmadıkları birçok çalışmada da sonuç olarak bildirilmektedir (Aksel ve Yılmaz Irmak, 2015; Akgül,2015; Can Yaşar, Şenol ve Akyol, 2015; Çopur, Balc1 ve Günay, 2019; Esin vd., 2020; Farrell ve Walsh, 2010; Kenny, 2004; McKee ve Dillenburger, 2009; Sarıbaş, 2013; Seth ve Srivastava, 2017; Tugay, 2008). Çocuk istismarının bildirimi konusunda yaşanan bu etik ikilemler, eğitim ve sağlık hizmeti sunucularının tanılama ve tedavi süreci konusunda yeterli bilgiye sahip olmamalarından da kaynaklanabilmektedir (WHO, 2017).

Dünya Sağlık Örgütü (2017) çocuk cinsel istismarını tanılama ve tedavi sürecinde iş yardımı olarak kullanılabilecek evrensel bakım yollarını gösteren bir akış şeması hazırlamıştır (Şekil 1). Bildirim sonrası süreçte çocuk cinsel istismarını tanılama ve tedavi sürecinde sağlık hizmeti sunucularının görevlerini özetleyen bu 
akış, öğretmenlerin de süreç konusundaki kaygılarının giderilmesine yardımcı olabilir.

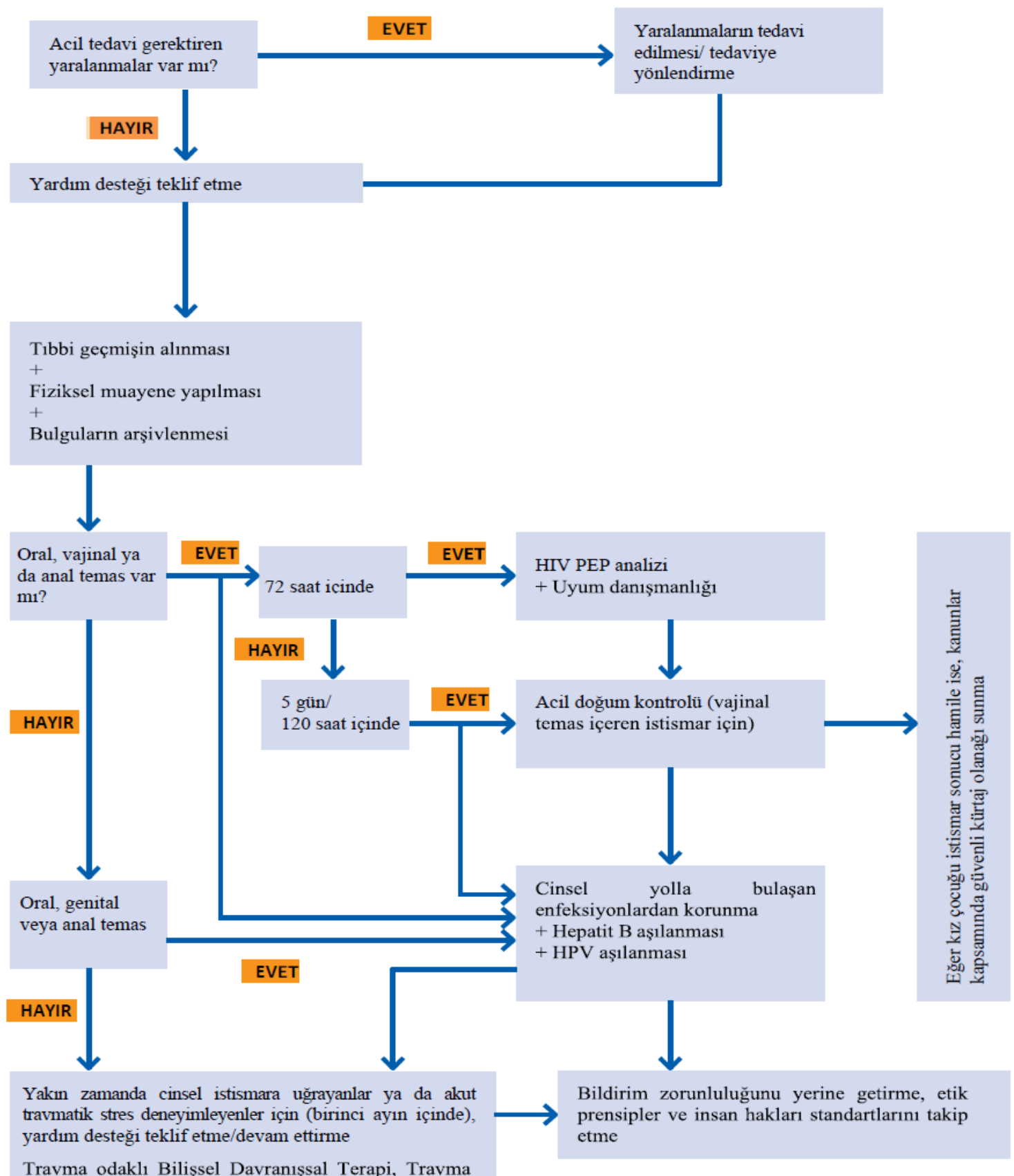
Sonrası Stres Bozukluğu yaşayan istismardan sağ kurtulan kișiler için göz önünde bulundurmalı, güvenli olan durumlarda da rahatsız edici olmayan bakıcıların da sürece dahil edilmesi

Duygusal ve davranışsal bozukluklar için uygun tedaviyi düşünme

\begin{abstract}
Acil tıbbi bakim gerekli değilse ya da başka koşullar var ise bildirim zorunluluğunun daha erken takip edilmesi gerekebilir.
\end{abstract}

Şekil 1. Cinsel istismarın tanı ve tedavi süreci akışı (WHO, 2017 s.42)

Şekil 1'de görüldüğü gibi cinsel istismar şüphesi bildirimi sonrası; çocuk veya vasi geçmişi elde etmek; belirtiler ve semptomlar için alternatif açıklamaları düşünmek; travma veya enfeksiyon kanıtlarını tanımlamak ve belgelemek; istismardan kaynaklanan tıbbi durumları teşhis etmek ve tedavi etmek, istismarla 
ilişkili olmayan tıbbi koşulları teşhis etmek ve tedavi etmek; ortaya çıkabilecek gelişimsel, duygusal veya davranışsal sorunları göz önünde bulundurmak; çocuğun güvenliğini değerlendirmek ve gerekirse çocuğa ve aileye uygun bir şekilde güvence vermek için koruyucu hizmetlere yönlendirmek; gelecekteki kararlar için bulguları belgelemek ve çocukların iyilik halini sağlamak ve korumak için çalışmalar yapılmaktadır (Marks, Lamb ve Tzioumi, 2009; Hornor vd., 2009).

Laraque vd. (2006) çocuk cinsel istismarını değerlendirme, tanılama ve tedavi süreçlerinde çocuğu bir bütün olarak değerlendirmenin ve bu süreçlerde travmayı en aza indirgemenin önemli olduğunu vurgulamaktadır. Bu bağlamda öğretmenlerin, çocuk cinsel istismarı ile karşılaştıklarında üzerlerine düşen görevi yerine getirebilmelerinde gerekli bilgilere sahip olmanın yanında bu konuda tutum ve davranışları da önem kazanmaktadır (Aral ve Gürsel, 2001; Can Yaşar, Karaca ve Kaya, 2018; Koç, Ekşi ve Türk, 2020; Ulum, 2020).

Öğretmenlerin çocuk cinsel istismarının bildirimi yükümlülükleri ve istismar belirtileri ile ilgili bilgi düzeylerini raporlayan çalışmalar dışında, öğretmenlerin çocuk cinsel istismarının bildirilmesi sürecindeki tutumlarını inceleyen araştırmalar da mevcuttur. Bu bağlamda öğretmenlerin kişisel özelliklerini değişken olarak ele almış uluslararası çalışmalar birbiriyle çelişen sonuçlara sahiptir. Alanyazındaki bu çalışmalarda cinsiyet (Crenshaw vd., 1995; Çapri ve Demiröz, 2016; Humphries vd., 2016; Kenny, 2001; Kenny, 2004), k1dem (Behun vd., 2019; Crenshaw vd., 1995; King, Reece, Bendel ve Patel, 1998; O'Toole vd., 1999), bildirim yükümlülüğüne dair bilgi sahibi olma (Abrahams, Casey ve Daro, 1992; Beck, Ogloff ve Corbishley, 1994; Hinson ve Fossey, 2000; Kenny, 2004; Walsh vd., 2008) ve bu konuda eğitim alma durumu (Akgül, 2015; Hawkins ve McCallum, 2001; Walsh vd., 2008; Zellman, 1990) değişkenleri incelenmiştir. Kuşkusuz bu etmenlerin belirlenmesi, öğretmenlerin bildirim yükümlülüklerini olumsuz etkileyen etmenlerin önüne geçilmesi açısından önemlidir. Bunun yanında, cinsel istismara maruz kalabilecek özellikle erken çocukluk dönemindeki çocuklarla ilgilenen okul öncesi ve sınıf öğretmenlerinin cinsel istismar şüphelerini bildirmelerini etkileyen etmenlerin bilimsel veriler ışığında açı̆̆a çıkarılması bu etmenlerin önüne geçmek bakımından gereklidir. Bu noktadan hareketle bu araştırmada, okul öncesi ve sinıf öğretmenlerinin çocuk cinsel istismarının bildirimine yönelik tutumlarını etkileyen etmenlerin incelenmesi amaçlanmıştır. Bu araştırmanın belirtilen amaç çerçevesinde Türkiye'de yapılmış çalışmalardan oluşan alanyazındaki boşluğu dolduracağı ve çocuk cinsel istismarının bildirimine olumsuz etki edebilecek değişkenlerin ilgili kurum ve kuruluşlar aracılığı ile iyileştirilmesine yönelik çalışmalara temel oluşturabileceği düşünülmektedir.

\section{Yöntem}

Araştırmada, öğretmenlerin çocuk cinsel istismarının bildirimine yönelik tutumlarını etkileyen etmenlerin incelenmesi amaçlandığından ilişkisel araştırma deseni kullanılmıştır. İlişkisel araştırma modeli, iki veya daha çok değişken arasındaki birlikte değişim varlığını veya derecesini belirlemeyi amaçlar, ancak nedensel ilişkiler ile ilgilenmez. Bu desende araştırmacı, değişkenleri etkileyen işlemler gerçekleştikten sonra değerlendirme sürecine dahil olur. Gruplardaki ya da puanlardaki değişkenlikler, katılımcıların bulundukları ortamların farklı olmasından, 
kalıtsal özelliklerdeki farklılıklardan ya da ikisinin kombinasyonundan dolayı ortaya çıkmış olabilir (Shavelson, 1996).

\section{Çalışma Grubu}

Araştırmanın çalışma evrenini, 2019-2020 eğitim-öğretim yılında Afyonkarahisar merkez ilçelerinde Milli Eğitim Müdürlüğüne bağlı anaokulları ve ilkokullarda görev yapan okul öncesi ve sınıf öğretmenleri oluşturmaktadır. Araştırmanın çalışma grubuna, amaçlı örnekleme yöntemine göre gönüllülük esasına dayalı olarak, 213 sinıf eğitimi ve 207 okul öncesi öğretmeni dahil edilmiştir. Bu doğrultuda mevcut araştırmaya toplam 420 öğretmen katılmıştır.

Araştırmaya dahil edilen öğretmenlerin demografik özellikleri incelendiğinde; $\% 50,7^{\prime}$ 'sinin sinıf öğretmeni, \%49,3'ünün okul öncesi öğretmeni olduğu; \%59,3'ünün kadın, \%40,7'sinin erkek olduğu; \%30'unun 20-30 yaş, \%37'inin 31-40 yaş ve \%33'ünün 41 ve üstü yaş aralığında olduğu; \%48,1'inin 1-10 yıllık, \%27,1'inin 11-20 yıllık, \%24,8'inin 21 ve üstü yıllık kıdeme sahip olduğu belirlenmiştir. Ayrıca öğretmenlerin \%10,7'sinin sınıfında 10-15 çocuk, \%28,6'sının sınıfında 16-20 çocuk, $\% 27,1^{\prime}$ inin sınıfında 21-25 çocuk, \%33,2'sinin sınıfında 26 çocuk ve daha fazlası bulunduğu; öğretmenlerin \%29,8'inin bu konuda eğitim aldı ̆̆ almadığı saptanmıştır.

\section{Veri Toplama Araçları}

Araştırmada veri toplama aracı olarak, öğretmenlerin kişisel bilgilerini belirlemek amacıyla "Genel Bilgi Formu" ve öğretmenlerin çocuk cinsel istismarının bildirimine yönelik tutumlarını belirlemek amacıyla "Çocuk Cinsel İstismarının Bildirimine Yönelik Öğretmen Tutum Ölçeği” kullanılmıştır.

Genel bilgi formu. Araştırmacılar tarafından geliştirilen formda; öğretmenlerin cinsiyeti, program türü, yaşı, sınıflarındaki çocuk sayısı ve bu konu ile ilgili eğitim alıp almadıklarına yönelik sorular yer almaktadır.

Çocuk cinsel istismarının bildirimine yönelik öğretmen tutum ölçeği. Orijinal adı Teachers' Reporting Attitude Scale for Child Sexual Abuse (TRAS-CSA) olan ölçek, Walsh, Rassafiani, Mathews, Farrel ve Butler (2010) tarafından geliştirilmiştir. Türkçeye uyarlama ve geçerlik-güvenirlik çalışması Can Yaşar, Karaca ve Kaya (2018) tarafından yapılmıştır. Likert tipi olan ölçek 18 maddeden oluşmakta; kesinlikle katılmıyorum (1), katılmıyorum (2), kararsızım (3), katılıyorum (4) ve kesinlikle katılıyorum (5) şeklinde puanlanmaktadır. Can Yaşar, Karaca ve Kaya (2018) tarafından uyarlama çalışmasında ölçeğe faktör analizi yapılmış ve maddeler "Etik", "Kişisel Kayg1", "Sosyal Kayg1" ve "Kararlılı" şeklinde dört faktöre ayrılmıştır. Ayrıca KMO (Kaiser-Meyer-Olkin Measure of Sampling Adequacy) değeri .80 olarak, güvenirlik katsayısı ise $a=.651$ olarak belirlenmiştir. Ölçeğe uygulanan madde toplam korelasyonlarının ise .250 ile .466 arasında olduğu saptanmış ve yeterli düzeyde olduğu tespit edilmiştir.

\section{Veri Toplama Süreci}

Araştırmada, öğretmenlerin çocuk cinsel istismarının bildirimine yönelik tutumlarını etkileyen etmenlerin inceleyebilmek amacıyla öncelikle çalışma grubunu belirleme çalışmaları yapılmıştır. Çalışma grubunu belirleyebilmek için Afyonkarahisar Milli Eğitim Müdürlüğü'nden gerekli izinler alınmıştır. Örneklem grubuna dahil edilecek 
olan 213 sınıf eğitimi ve 207 okul öncesi öğretmeni ile ölçme aracını uygulamaya başlamadan önce araştırmacı tarafından açıklamalarda bulunulmuştur. ölçme aracı araştırmacı tarafından öğretmenlere dağıtılım ve ölçme aracı doldurulduktan sonra tekrar alınmıştır.

\section{Verilerin Analizi}

Araştırmaya dahil edilen öğretmenlerin genel bilgi formunda yer alan kişisel bilgileri frekans ve yüzde dağılımları halinde verilmiştir. “Çocuk Cinsel İstismarının Bildirimine Yönelik Öğretmen Tutum Ölçeği" nden elde edilen verilerin analizinde; öncelikle puanların normal dağılımına bakılmış, normal dağılım gösterip göstermediği Kolmogorov-Smirnoff (K-S) Testi ile incelenmiştir. Ölçeğe verilen yanıtların puanları ile homojenliğe bakıldığında değerlerin 0,05 ten küçük olduğu yani normal dağılım göstermediği belirlenmiş (Bütüner, 2008) ve verilerin analizinde non-parametrik testler kullanılmıştır. Buradan hareketle öğretmenlerin cinsiyet, mezun olunan program, çocuk koruma kanunu hakkında bilgilendirilme, daha önce istismar ile ilgili herhangi bir eğitim alıp almadıkları, milli eğitim politikalarına göre profesyonel anlamda çocuk ihmal ve istismarı şüphesini bildirme sorumluluğu değişkenlerinde Manny Whitney U Testi ile kıdem değişkenlerinde Kruskall Wallis $\mathrm{H}$ Testi kullanılarak analiz edilmiştir.

\section{Bulgular}

Okul öncesi ve sınıf öğretmenlerinin çocuk cinsel istismarının bildirimine yönelik tutumlarını etkileyen etmenlerin incelenmesi amacıyla yapılan araştırmadan elde edilen bulgular tablolar halinde sunulmuştur.

Tablo 1

Öğretmenlerin Cinsiyetlerine Göre Çocuk Cinsel İstismarnnın Bildirimine Yönelik Tutumlarına İlişkin Mann-Whitney U Testi Sonuçları

\begin{tabular}{llcccccc}
\hline Alt Faktörler & Cinsiyet & $n$ & $\bar{X}$ & ss & Sira Ort. & $z$ & $p$ \\
\hline \multirow{2}{*}{ Etik } & Kadın & 300 & 3,684 &, 532 & 217,27 & $-1,845$ & .065 \\
& Erkek & 120 & 3,552 &, 647 & 193,58 & & \\
\multirow{2}{*}{ Kişisel Kayg1 } & Kadın & 300 & 3,203 &, 731 & 216,49 & $-1,604$ & .109 \\
& Erkek & 120 & 3,004 &, 840 & 195,52 & & \\
\multirow{2}{*}{ Sosyal Kayg1 } & Kadın & 300 & 2,327 &, 787 & 200,65 & $-2,642$ & $.008^{*}$ \\
& Erkek & 120 & 2,566 &, 876 & 235,14 & & \multirow{2}{*}{ Kararlı1ık } \\
& Kadın & 300 & 4,262 &, 738 & 223,27 & $-3,437$ & $.001^{*}$ \\
\multirow{2}{*}{ Toplam } & Erkek & 120 & 3,925 &, 850 & 178,58 & & \multirow{2}{*}{$.025^{*}$} \\
& Kadın & 300 & 3,350 &, 396 & 218,89 & $-2,241$ & \\
\hline
\end{tabular}

${ }^{*} \mathrm{p}<.05$

Tablo 1 incelendiğinde, öğretmenlerin cinsiyetlerine göre Çocuk Cinsel İstismarının Bildirimine Yönelik Tutum Ölçeği alt boyutlarından Sosyal Kaygı ( $\mathrm{z}=-$ $2,642, \mathrm{p}=.008, \mathrm{p}<.05)$, Kararlılık $(\mathrm{z}-3,437, \mathrm{p}=.001, \mathrm{p}<.05)$ alt boyutlarında ve toplamda $(\mathrm{z}=-2,241, \mathrm{p}=.025, \mathrm{p}<.05)$ istatistiksel olarak anlamlı fark olduğu görülmektedir. Buna göre, Sosyal Kayg1 alt boyutunda erkek öğretmenlerin puan ortalamasının kadın öğretmenlerin puan ortalamasından daha yüksek olduğu; Kararlılık alt boyutunda 
ise kadın öğretmenlerin puan ortalamasının erkek öğretmenlerin puan ortalamasından daha yüksek olduğu söylenebilir.

Tablo 2

Öğretmenlerin Mezun Oldukları Programa Göre Çocuk Cinsel İstismarının Bildirimine Yönelik Tutumlarnna İlişkin Mann-Whitney U Testi Sonuçları

\begin{tabular}{lccccccc}
\hline Alt Faktörler & Mezun Olunan Program & $n$ & $\bar{X}$ & ss & Stra Ort. & $z$ & $p$ \\
\hline \multirow{2}{*}{ Etik } & Sinıf Eğitimi & 213 & 3,568 &, 614 & 194,27 & $-2,839$ & $.005^{*}$ \\
& Okul Öncesi Eğitim & 207 & 3,727 &, 509 & 227,20 & & \\
\multirow{2}{*}{ Kişisel Kayg1 } & Sinıf Eğitimi & 213 & 3,061 &, 782 & 199,32 & $-1,920$ & .055 \\
& Okul Öncesi Eğitim & 207 & 3,233 &, 745 & 222,01 & & \\
\multirow{2}{*}{ Sosyal Kayg1 } & Sinıf Eğitimi & 213 & 2,522 &, 837 & 229,66 & $-3,296$ & $.001^{*}$ \\
& Okul Öncesi Eğitim & 207 & 2,265 &, 782 & 190,78 & & \\
\multirow{2}{*}{ Kararlılık } & Sinıf Eğitimi & 213 & 4,002 &, 764 & 185,14 & $-4,379$ & $.000^{*}$ \\
& Okul Öncesi Eğitim & 207 & 4,334 &, 774 & 236,59 & & \\
Toplam & Sinıf Eğitimi & 213 & 3,263 &, 451 & 197,12 & $-2,293$ & $.022^{*}$ \\
& Okul Öncesi Eğitim & 207 & 3,372 &, 405 & 224,27 & & \\
& & & & & & &
\end{tabular}

Tablo 2 incelendiğinde, öğretmenlerin mezun oldukları programa göre Çocuk Cinsel İstismarının Bildirimine Yönelik Tutum Ölçeği alt boyutlarından Etik $(\mathrm{z}=-$ 2,839, $\mathrm{p}=.005, \mathrm{p}<.05)$, Sosyal Kayg1 $(\mathrm{z}=-3,296, \mathrm{p}=.001, \mathrm{p}<.05)$, Kararlilik $(\mathrm{z}=-4,379$, $\mathrm{p}=.000, \mathrm{p}<.05)$ alt boyutlarinda ve toplamda $(\mathrm{z}=-2,293, \mathrm{p}=.022, \mathrm{p}<.05)$ istatistiksel olarak anlamlı fark olduğu görülmektedir. Buna göre, Sosyal Kaygı alt boyutunda sınıf öğretmenlerinin puan ortalamasının okul öncesi öğretmenlerinin puan ortalamasından daha yüksek olduğu; Etik ve Kararlılık alt boyutlarında ise okul öncesi öğretmenlerin puan ortalamasının sınıf öğretmenlerinin puan ortalamasından daha yüksek olduğu söylenebilir.

Tablo 3 incelendiğinde, okul öncesi öğretmenlerin meslekteki kıdemlerine göre Çocuk Cinsel İstismarının Bildirimine Yönelik Tutum Ölçeği alt boyutlarından Kişisel Kayg1 $(\chi 2=12,008, p=.035, p<.05)$ alt boyutunda 21-25 y1llık öğretmenler ile 15, 6-10,11-15 y1l kıdeme sahip öğretmenler arasında 21-25 yıl kıdeme sahip öğretmenlerin lehine anlamlı farklılık olduğu görülmektedir. Bundan farklı olarak sınıf öğretmenlerinin Çocuk Cinsel İstismarının Bildirimine Yönelik Tutum Ölçeği alt boyutlarından Kararlılik $(\chi 2=11,156, \mathrm{p}=.048, \mathrm{p}<.05)$ alt boyutunda 6-10 y1l k1deme sahip öğretmenlere nazaran 21-25 yıl kıdeme sahip öğretmenlerin lehine anlamlı farklılık olduğu görülmektedir. Buna göre, bildirim konusunda okul öncesi öğretmenlerinin kıdemleri arttıkça kişisel kaygılarının, sınıf öğretmenlerinin ise kıdemleri arttıkça kararlılıklarının arttığı söylenebilir. 
Tablo 3

Öğretmenlerin Kıdemlerine Göre Çocuk Cinsel İstismarının Bildirimine Yönelik Tutumlarnna İlişkin Kruskall-Wallis H Testi Sonuçları

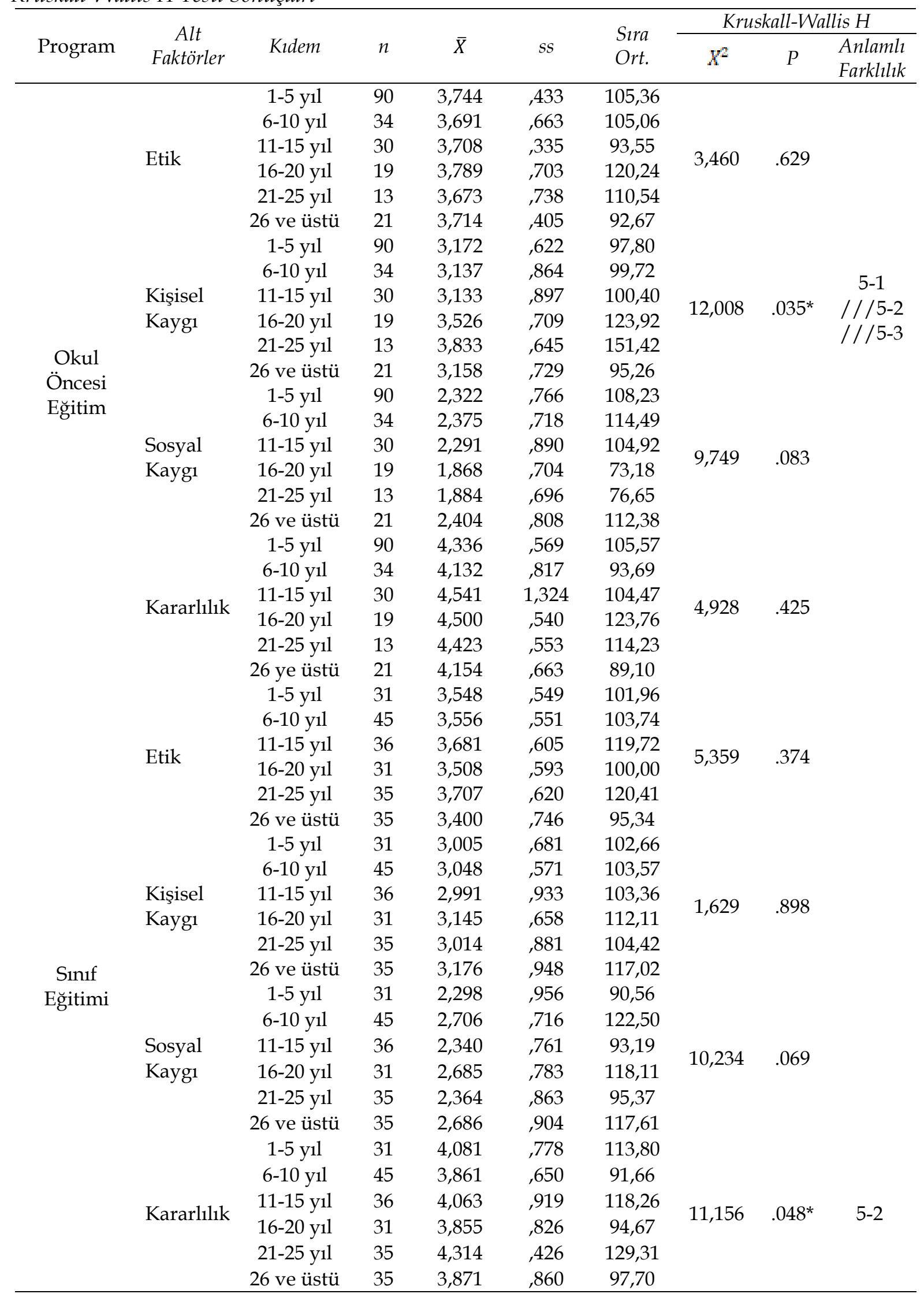


Tablo 4

Öğretmenlerin Çocuk İhmal ve İstismarn Konusunda Ĕ̆itim Alma Durumlarna Göre Çocuk Cinsel İstismarının Bildirimine Yönelik Tutumlarnna İlişkin Mann-Whitney U Testi Sonuçları

\begin{tabular}{|c|c|c|c|c|c|c|c|c|}
\hline Program & Alt Faktörler & Eğitim Alma & $n$ & $\bar{X}$ & SS & Stra Ort. & $z$ & $p$ \\
\hline \multirow{10}{*}{$\begin{array}{c}\text { Okul Öncesi } \\
\text { Eğitimi }\end{array}$} & \multirow{2}{*}{ Etik } & Evet & 59 & 3,694 & 493 & 97,26 & \multirow{2}{*}{1,051} & \multirow{2}{*}{.293} \\
\hline & & Hayır & 148 & 3,739 & ,516 & 106,69 & & \\
\hline & \multirow{2}{*}{ Kişisel Kayg1 } & Evet & 59 & 3,279 & 792 & 10,86 & \multirow{2}{*}{ 434 } & \multirow{2}{*}{.664} \\
\hline & & Hayır & 148 & 3,215 & 727 & 102,86 & & \\
\hline & \multirow{2}{*}{ Sosyal Kayg1 } & Evet & 59 & 2,131 & 766 & 93,31 & \multirow{2}{*}{1,630} & \multirow{2}{*}{.103} \\
\hline & & Hayır & 148 & 2,319 & 785 & 108,26 & & \\
\hline & \multirow{2}{*}{ Kararlılık } & Evet & 59 & 4,296 & 668 & 104,86 & \multirow{2}{*}{ 133 } & \multirow{2}{*}{.895} \\
\hline & & Hayır & 148 & 4,349 & 814 & 103,66 & & \\
\hline & \multirow{2}{*}{ Toplam } & Evet & 59 & 3,342 & 397 & 99,19 & \multirow{2}{*}{,730 } & \multirow{2}{*}{ 466 } \\
\hline & & Hayır & 148 & 3,384 & 408 & 105,92 & & \\
\hline \multirow{10}{*}{ Sınıf Eğitimi } & \multirow{2}{*}{ Etik } & Evet & 59 & 3,728 & 513 & 124,11 & \multirow{2}{*}{2,552} & \multirow{2}{*}{$.011^{*}$} \\
\hline & & Hayır & 154 & 3,506 & 639 & 100,44 & & \\
\hline & \multirow{2}{*}{ Kişisel Kaygı } & Evet & 59 & 2,983 & 762 & 97,27 & \multirow{2}{*}{1,430} & \multirow{2}{*}{.153} \\
\hline & & Hayır & 154 & 3,092 & 790 & 110,73 & & \\
\hline & \multirow{2}{*}{ Sosyal Kaygı } & Evet & 59 & 2,245 & 728 & 85,43 & \multirow{2}{*}{3,174} & \multirow{2}{*}{$.002^{*}$} \\
\hline & & Hayır & 154 & 2,628 & 853 & 115,26 & & \\
\hline & \multirow{2}{*}{ Kararlılık } & Evet & 59 & 4,237 & 623 & 126,24 & \multirow{2}{*}{2,841} & \multirow{2}{*}{$.004^{*}$} \\
\hline & & Hayır & 154 & 3,912 & 795 & 99363 & & \\
\hline & \multirow{2}{*}{ Toplam } & Evet & 59 & 3,263 & 391 & 104,48 & \multirow{2}{*}{,369 } & \multirow{2}{*}{.712} \\
\hline & & Hayır & 154 & 3,263 & 473 & 107,96 & & \\
\hline
\end{tabular}

${ }^{*} \mathrm{p}<.05$

Tablo 4 incelendiğinde, öğretmenlerin çocuk ihmal ve istismarı konusunda eğitim alma durumuna göre Çocuk Cinsel İstismarının Bildirimine Yönelik Tutum Ölçeği alt boyutlarında, okul öncesi öğretmenlerin puanlarında herhangi bir farklılık olmadığ1; sınıf öğretmenlerinin Etik $(z=2,552, p=.011, p<.05)$, Sosyal Kayg1 $(z=3,174$ $\mathrm{p}=.002, \mathrm{p}<.05)$ ve Kararlilik $(\mathrm{z}=2,841, \mathrm{p}=.004, \mathrm{p}<.05)$ alt boyutlarında istatistiksel olarak anlamlı farklılık görülmektedir. Buna göre, eğitimin etik ve kararlılık üzerinde olumlu etki yarattığı ve eğitim almayan öğretmenlerin sosyal kaygılarının daha yüksek olduğu söylenebilir. Bu sonuçlar ve okul öncesi öğretmenlerinin puan ortalamaları dikkate alındığında, eğitim alan öğretmenlerin çocuk cinsel istismarının bildirimine yönelik tutumlarının olumlu yönde etkilendiği sonucu çıkarılabilir.

Tablo 5 incelendiğinde, öğretmenlerin Milli Eğitim politikaları kapsamında çocuk ihmal ve istismarı şüphesi bildirim yükümlülüğü durumuna göre Çocuk Cinsel İstismarının Bildirimine Yönelik Tutum Ölçeği puanları alt boyutlarında; okul öncesi öğretmenlerinin Kararlılık $(\mathrm{z}=2,304, \mathrm{p}=.021, \mathrm{p}<.05)$ alt boyutunda, sinıf öğretmenlerinin ise Etik $(\mathrm{z}=3,043, \mathrm{p}=.002, \mathrm{p}<.05)$, Sosyal Kayg1 $(\mathrm{z}=4,068, \mathrm{p}=.000$, $\mathrm{p}<.05)$ ve Kararlilik $(\mathrm{z}=2,977, \mathrm{p}=.003, \mathrm{p}<.05)$ alt boyutlarında istatistiksel olarak anlamlı fark görülmektedir. Bu bulgular ve ortalama puanlar dikkate alındığında, okul öncesi ve sınıf öğretmenlerinden Milli Eğitim politikalarına göre bildirim yükümlülüğü olduğunu düşünenlerin tüm boyutlarda yüksek puan aldığ1 söylenebilir. 
Tablo 5

Öğretmenlerin Milli Ĕ̆itim Politikaları Kapsamında Çocuk İhmal ve İstismar Şüphesi Bildirim Yükümlülüğ̈̈ Durumuna Göre Çocuk Cinsel İstismarının Bildirimine Yönelik Tutumlarına İlişkin Mann-Whitney U Testi Sonuçları

\begin{tabular}{|c|c|c|c|c|c|c|c|c|}
\hline Program & Alt Faktörler & $\begin{array}{c}\text { Bildirim } \\
\text { Yükümlülü̈̆̈̈̈ }\end{array}$ & $n$ & $\bar{X}$ & ss & Stra Ort. & $z$ & $p$ \\
\hline \multirow{10}{*}{$\begin{array}{c}\text { Okul Öncesi } \\
\text { Eğitim }\end{array}$} & \multirow{2}{*}{ Etik } & Evet & 197 & 3,727 & 0,518 & 104,44 & \multirow{2}{*}{479} & \multirow{2}{*}{.632} \\
\hline & & Hayır & 10 & 3,725 & 0,322 & 95,40 & & \\
\hline & \multirow[b]{2}{*}{ Kişisel Kayg1 } & Evet & 197 & 3,245 & 0,747 & 105,11 & \multirow[b]{2}{*}{1,183} & \multirow[b]{2}{*}{.237} \\
\hline & & Hayır & 10 & 3,000 & 0,707 & 82,20 & & \\
\hline & \multirow{2}{*}{ Sosyal Kayg1 } & Evet & 197 & 2,260 & 0,778 & 103,55 & \multirow{2}{*}{479} & \multirow{2}{*}{.632} \\
\hline & & Hayır & 10 & 2,375 & 0,899 & 112,80 & & \\
\hline & \multirow{2}{*}{ Kararlılık } & Evet & 197 & 4,359 & 0,772 & 106,14 & \multirow{2}{*}{2,304} & \multirow{2}{*}{$.021^{*}$} \\
\hline & & Hayır & 10 & 3,850 & 0,689 & 61,90 & & \\
\hline & \multirow{2}{*}{ Toplam } & Evet & 197 & 3,381 & 0,396 & 105,07 & \multirow{2}{*}{1,146} & \multirow{2}{*}{.252} \\
\hline & & Hayır & 10 & 3,211 & 0,555 & 82,85 & & \\
\hline \multirow{10}{*}{ Sınıf Eğitimi } & \multirow{2}{*}{ Etik } & Evet & 187 & 3,594 & 0,636 & 111,71 & \multirow{2}{*}{3,043} & \multirow{2}{*}{$.002^{*}$} \\
\hline & & Hayır & 26 & 3,385 & 0,389 & 73,13 & & \\
\hline & \multirow{2}{*}{ Kişisel Kayg1 } & Evet & 187 & 3,029 & 0,803 & 104,53 & \multirow{2}{*}{1,572} & \multirow{2}{*}{.116} \\
\hline & & Hayır & 26 & 3,301 & 0,566 & 124,75 & & \\
\hline & \multirow{2}{*}{ Sosyal Kayg1 } & Evet & 187 & 2,439 & 0,835 & 100,62 & \multirow{2}{*}{4,068} & \multirow{2}{*}{$.000^{*}$} \\
\hline & & Hayır & 26 & 3,125 & 0,567 & 152,88 & & \\
\hline & \multirow{2}{*}{ Kararlılık } & Evet & 187 & 4,049 & 0,770 & 111,65 & \multirow{2}{*}{2,977} & \multirow{2}{*}{$.003^{*}$} \\
\hline & & Hayır & 26 & 3,663 & 0,640 & 73,54 & & \\
\hline & \multirow[t]{2}{*}{ Toplam } & Evet & 187 & 3,250 & 0,469 & 104,99 & \multirow{2}{*}{1,278} & \multirow[t]{2}{*}{.201} \\
\hline & & Hayır & 26 & 3,361 & 0,286 & 121,46 & & \\
\hline
\end{tabular}

${ }^{*} \mathrm{p}<.05$

Tablo 6 incelendiğinde, öğretmenlerin Çocuk Koruma Kanunu (ÇKK) hakkında bilgi sahibi olma durumuna göre Çocuk Cinsel İstismarının Bildirimine Yönelik Tutum Ölçeği puanları alt boyutlarında; okul öncesi öğretmenlerinin Sosyal Kayg1 $(z=2,599, p=.009, p<.05)$ alt boyutunda, sınıf öğretmenlerinin ise Etik $(z=2,564$, $\mathrm{p}=.010, \mathrm{p}<.05)$ ve Sosyal Kayg1 $(\mathrm{z}=2,399, \mathrm{p}=.016, \mathrm{p}<.05)$ alt boyutlarında istatistiksel olarak anlamlı fark görülmektedir. Buna göre, Çocuk Koruma Kanunu konusunda bilgi sahibi olan okul öncesi ve sınıf öğretmenlerinin sosyal kaygı düzeylerinin daha yüksek olduğu; sınıf öğretmenlerinin de etik boyutunda daha yüksek puan aldığ söylenebilir. 
Tablo 6

Öğretmenlerin Çocuk Koruma Kanunu (ÇKK) Hakkında Bilgi Sahibi Olma Durumuna Göre Çocuk Cinsel İstismarının Bildirimine Yönelik Tutumlarına İlişkin Mann-Whitney U Testi Sonuçları

\begin{tabular}{|c|c|c|c|c|c|c|c|c|}
\hline Program & Alt Faktörler & ÇKK & $n$ & $\bar{X}$ & ss & Stra Ort. & $z$ & $p$ \\
\hline \multirow{10}{*}{$\begin{array}{l}\text { Okul Öncesi } \\
\text { Eğitim }\end{array}$} & \multirow{2}{*}{ Etik } & Evet & 52 & 3,688 &, 560 & 97,02 & \multirow{2}{*}{,999 } & \multirow{2}{*}{.318} \\
\hline & & Hayır & 155 & 3,740 & ,493 & 106,34 & & \\
\hline & \multirow{2}{*}{ Kişisel Kayg1 } & Evet & 52 & 3,340 & 853 & 110,30 & \multirow[b]{2}{*}{,879 } & \multirow[b]{2}{*}{.380} \\
\hline & & Hayır & 155 & 3,198 & ,706 & 101,89 & & \\
\hline & \multirow{2}{*}{ Sosyal Kayg1 } & Evet & 52 & 2,034 & ,833 & 85,41 & \multirow{2}{*}{2,599} & \multirow{2}{*}{$.009^{*}$} \\
\hline & & Hayır & 155 & 2,344 & ,752 & 110,24 & & \\
\hline & \multirow{2}{*}{ Kararlılık } & Evet & 52 & 4,423 & 1,131 & 104,91 & \multirow{2}{*}{ 129 } & \multirow{2}{*}{.898} \\
\hline & & Hayır & 155 & 4,305 & 613 & 103,69 & & \\
\hline & \multirow{2}{*}{ Toplam } & Evet & 52 & 3,368 & 451 & 102,38 & \multirow{2}{*}{,226 } & \multirow{2}{*}{.821} \\
\hline & & Hayır & 155 & 3,375 & ,390 & 104,55 & & \\
\hline \multirow{10}{*}{ Sınıf Eğitimi } & \multirow{2}{*}{ Etik } & Evet & 67 & 3,728 & 486 & 122,71 & \multirow[b]{2}{*}{2,564} & \multirow[b]{2}{*}{$.010^{*}$} \\
\hline & & Hayır & 146 & 3,495 & 654 & 99,79 & & \\
\hline & \multirow{2}{*}{ Kişisel Kayg1 } & Evet & 67 & 2,975 & 842 & 97,66 & \multirow{2}{*}{1,502} & \multirow{2}{*}{.133} \\
\hline & & Hayır & 146 & 3,102 & 753 & 111,28 & & \\
\hline & \multirow{2}{*}{ Sosyal Kayg1 } & Evet & 67 & 2,332 & 801 & 92,10 & \multirow{2}{*}{2,399} & \multirow{2}{*}{$.016^{*}$} \\
\hline & & Hayır & 146 & 2,610 & 842 & 113,84 & & \\
\hline & \multirow{2}{*}{ Kararlılık } & Evet & 67 & 4,164 & ,636 & 119,13 & \multirow{2}{*}{1,961} & \multirow{2}{*}{.050} \\
\hline & & Hayır & 146 & 3,928 & 808 & 101,43 & & \\
\hline & \multirow{2}{*}{ Toplam } & Evet & 67 & 3,264 & 421 & 105,48 & \multirow{2}{*}{,244 } & \multirow{2}{*}{.807} \\
\hline & & Hayır & 146 & 3,263 & ,466 & 107,70 & & \\
\hline
\end{tabular}

${ }^{*} \mathrm{p}<.05$

\section{Tartışma, Sonuç ve Öneriler}

Okul öncesi ve sınıf öğretmenlerinin çocuk cinsel istismarının bildirilmesine yönelik tutumlarını etkileyen etmenlerin incelenmesi amacıyla yapılan bu araştırmada, ilk olarak cinsiyet değişkenine göre çocuk cinsel istismarının bildirimine yönelik ölçek alt boyutlarında erkek öğretmenler ile kadın öğretmenler arasında istatistiksel olarak anlamlı farklılıklar göze çarpmaktadır. Buna göre, erkek öğretmenler bildirim sürecinde kadın öğretmenlere göre daha fazla sosyal kaygı hissettiklerini rapor ederken; kadın öğretmenler de kararlılık konusunda erkek öğretmenlere göre daha sağlam bir irade sergileyeceklerini puan ortalamalarıyla ifade etmişlerdir. Elde edilen bu sonuç, alanyazındaki ilgili çalışmalardan farklı bir çıkarıma işaret etmektedir. Bu konuda Çapri ve Demiröz (2016), eğitimcilerin cinsiyeti ile cinsel istismar bildirimine yönelik tutumları arasında düşük bir ilişki düzeyi tespit etmişler ve cinsiyetten bağımsız olarak öğretmenlerin bildirim sürecinde benzer tutumlar sergilediklerini ifade etmişlerdir. Alanyazında cinsiyete bağlı olarak öğretmenlerin cinsel istismarın bildirimindeki tutum farklılıklarını irdeleyen çalışma örnekleri (Crenshaw vd., 1995; Humphries vd., 2016; Kenny, 2001; Kenny, 2004; O'Toole vd., 1999) mevcuttur ve birbirinden farklı sonuçlar rapor etmişlerdir. Bunun nedenini Walsh vd. (2012) çalışmaların çocuk cinsel istismarının bildirilmine yönelik tutumlar üzerinde cinsiyet değişkeni incelenirken farklı ölçeklerden yararlanılması; Hornor (2010) da kadınların cinsel istismara daha fazla maruz kaldıkları için çocuk cinsel istismarı olasılığına karşı hiper-uyanık oldukları şeklinde açıklamıştır. Bu çalışmadan elde edilen sonuca 
göre erkek öğretmenlerin bildirim sürecinde daha fazla sosyal kaygı hissetmelerinin nedeni toplumsal kaygılar olabilmektedir. Buna göre, bir erkek öğretmenin çocuk üzerinde cinsel istismara dair fiziksel belirtilere ulaşmasının zorluğu, bildirimde bulunduğu zaman adının lekelenebileceği kaygısı, bildirim sonucunda çevre ve ailelerden gelecek karşı tepkiler, okuldaki çocuklar ve çocukların aileleriyle ilişkilerinin bozulacağı endişesi ve her ne kadar tam emin olmak mümkün olmasa da olası asılsız bir bildirimde bulunduktan sonra çocuğun ailesinden kopartılıp koruma altına alınması ihtimali erkek öğretmenlerin sosyal kaygı hissetmesinin nedenleri arasında sayllabilir. (Crenshaw vd., 1993; Kenny, 2001). Buna ek olarak, adaleti sağlama ve ahlak konusunda Kohlberg (1973) ve Gilligan'ın (1982) cinsiyet farklılıklarına işaret etmiş olmasına dayanarak erkek öğretmenlerin cinsel istismar gibi hassas bir suçlamada yanlış hüküm vermekten ve yanlış anlaşılmaktan çekindiği varsayımı da geçerli olabilir. Bu olası nedenlerin daha net bir şekilde belirlenebilmesi ve cinsiyet bazında önüne geçilmesi için bu konuda cinsiyet farklılığına yoğunlaşan bilimsel çalışmalar yapılabilir.

Araştırmada, sınıf öğretmenleri ile okul öncesi öğretmenlerinin çocuk cinsel istismarının bildirilmesine yönelik tutumları bakımından aralarındaki farklılıklar da incelenmiş ve istatistiksel olarak anlamlı şekilde sınıf öğretmenlerinin okul öncesi öğretmenlerine nazaran bildirim sürecinde daha fazla sosyal kayg1 hissettikleri sonucuna ulaşılmıştır. Buna ek olarak, okul öncesi öğretmenlerinin sınıf öğretmenlerine göre bildirim sürecinde etik sorumlulukları daha fazla hissettikleri ve süreçte daha kararlı bir yol izledikleri de belirlenmiştir. Okul öncesi öğretmenlerinin eğitim sürecinde çocuklarla daha fazla yakınlaşma olanağının olması, eğitim sürecine paralel olarak özbakım becerilerinde çocuklara çoğu zaman yardımcı olmak durumunda kaldıkları düşünüldüğünde bir okul öncesi öğretmeninin sinıf öğretmenine göre cinsel istismar belirtilerini daha kolay fark edebileceği ihtimali güçlüdür. Bir önceki sonuca paralel olarak okul öncesi öğretmenliği alanında ezici çoğunluğa sahip kadın öğretmenlerin yine sosyal kaygıdan uzak davranmış olmaları da ihtimal dahilindedir. Alanyazında çocuk cinsel istismarının bildirimi sürecinde öğretmenlerin tutumunu branşlara göre karşılaştıran bir çalışmaya rastlanmamıştır. Ancak bu çalışmadan elde edilen bu sonucun gelecekteki araştırmalarda tekrar ele alınıp farklı branşlara göre değişik örneklem gruplarıyla tekrar çalışılması önerilebilir.

Mesleki kıdeme göre öğretmenlerin çocuk cinsel istismarının bildirimine yönelik tutumları incelendiğinde, kıdemli okul öncesi öğretmenlerinin yeni mezun veya 15 yıla kadar deneyimli meslektaşlarına göre daha çok kişisel kaygı hissettikleri belirlenmiştir. Araştırmada ilgi çeken başka bir bulgu ise mesleğinde 21-15 yıl arası deneyime sahip sınıf öğretmenlerin daha az deneyime sahip meslektaşlarına göre çocuk cinsel istismarının bildirilmesi sürecinde daha kararlı olduklarıdır. Bu sonuç, daha önce yürütülmüş çalışmalardan (Crenshaw vd., 1995; Kenny, 2001; King, Reece, Bendel ve Patel, 1998; O'Toole vd., 1999) elde edilen sonuçlara göre farklılık göstermektedir. Öğretmenlerin çocuk cinsel istismarını bildirmelerindeki kararlılıklarını etkileyen bir husus da Gönültaş'ın da (2016) belirttiği üzere mağdurların ilk bildirimde isteksiz olmaları, süreç esnasında caymaları, anne babaların mahkeme sürecini yaşamak istememeleri gibi nedenler olabilir. Böyle durumlarda öğretmenler bildirimde bulunup sonrası süreçte yalnız kalmak istemiyor 
olabilirler. Alanyazındaki çoğu çalışmada kıdem yükseldikçe öğretmenlerin daha kararlı ve kişisel kaygılardan uzak bir şekilde süreci yönettiklerine dair bulgular mevcuttur (Behun vd., 2019; Akgül, 2015; Choo, Walsh, Marret, Chinna ve Tey, 2013). $\mathrm{Bu}$ araştırmaya katılan okul öncesi öğretmenlerinden kıdemli olanların çocuk cinsel istismarının bildirim sürecinde daha fazla kişisel kaygı hissediyor olacaklarının işaretini sergilemiş olmaları ilginç bir sonuçtur. Bu noktada, mesleki hizmet yılı daha çok olan öğretmenlerin toplum içinde kötü anılmaya dair ve istismar edilen çocuğun anne babasıyla ilişkilerinin bozulmasına yönelik kişisel kaygılarının; bu öğretmenleri bildirimde bulunmaktan alıkoyabileceği ifade edilmektedir (Haj-Yahia ve AttarSchwartz, 2008).

Araştırmaya katılan öğretmenlerin daha önce çocuk ihmal ve istismarı konusunda eğitim alma durumuna göre çocuk cinsel istismarının bildirimine yönelik tutumlarındaki farklılık incelendiğinde, eğitimin etik ve kararlılık üzerinde olumlu etki yarattığ1 ve eğitim almayan öğretmenlerin sosyal kaygılarının daha yüksek olduğu belirlenmiştir. Bu sonuçlar ve öğretmenlerin puan ortalamaları da dikkate alındığında, eğitim alan öğretmenlerin çocuk cinsel istismarının bildirimine yönelik tutumlarının olumlu yönde etkilendiği sonucunu çıkarmak mümkündür. Çocuklara yönelik ihmal ve istismar konusunda daha önce eğitim almış öğretmenlerin olası bir süreçte daha kararlı olmaları ve kendilerine daha fazla güveniyor olmaları beklenen bir sonuçtur. $\mathrm{Bu}$ sonuçla paralellik gösteren diğer bir araştırmada cinsel istismar bildirimine ilişkin eğitim alan öğretmen grubunun; bu konuda eğitim almayan öğretmenlere kıyasla, istismar belirtilerini tanımlayabilme noktasında kendilerine çok daha fazla güvendikleri ortaya çıkmıştır (Hawkins ve McCallum, 2001). Cinsel istismar bildirimine ilişkin araştırmada, çalışılan okulun karakteristiğinin, çocuk istismarına ilişkin bilgi düzeyi ve konuya ilişkin alınan eğitimin etkili olduğunu (Walsh vd.,2008; Kenny, 2004) ve bildirimde bulunmanın çocuğa yarar sağlayacağ tutumunun; cinsel istismar bildirimiyle ilişkili olduğu ifade edilmektedir (Zellman, 1990). Milli Eğitim Bakanlığı politikalarına göre profesyonel anlamda çocuk ihmal ve istismarı şüphesini bildirmekte kendilerini sorumlu hissedip hissetmediklerine göre öğretmenlerin tutumlarındaki farklılık incelendiğinde; politikaları benimseyen okul öncesi ve sınıf öğretmenleri mevcut politikaları içselleştirememiş öğretmenlere göre kararlılık açısından daha yüksek puanlar almışlardır. Buna ek olarak sınıf öğretmenlerinden Milli Eğitim Bakanlığı çocuk ihmal ve istismarının bildirimine yönelik politikaları olumlu bulanlar daha yüksek etik ve daha düşük sosyal kaygı puan ortalamaları elde etmişlerdir. Son olarak, Çocuk Koruma Kanunu (ÇKK) hakkında bilgi sahibi olma durumuna göre araştırmaya dahil olan öğretmenlerin tutumları arasında farklılıklar olup olmadığı incelenmiştir. Buna göre Çocuk Koruma Kanunu (ÇKK) hakkında bilgi sahibi olan öğretmenlerin, istatistiksel olarak daha az sosyal kaygı hissettikleri belirlenmiştir. Alanyazında bu iki sonucun tartışılabileceği tek bir çalışmaya rastlanmıştır. Bu çalışmaya benzer sonuç rapor eden Walsh, Mathews, Rassafiani, Farrell ve Butler (2013), ulusal eğitim politikaları ve çocuk koruma kanunu ile birlikte cinsel istismarın bildirilmemesine dair ceza kanunu maddeleri çerçevesinde kendilerine verilmiş cinsel istismar bildirim yükümlülüklerini özümsemiş eğitimcilerin istismar bildirim sürecinde kendilerinden daha emin ve kararlı hareket ettikleri sonucuna ulaşmıştır.

Bu sonuçlar doğrultusunda aşağıdaki öneriler sunulabilir: 
Alanyazına daha çok katkı sağlanması amacıyla çocuk cinsel istismarının bildirilmesini etkileyen etmenler açısından değişik branş öğretmenleri üzerinde daha geniş katılımlı olarak farklı değişkenlerle bu araştırma tekrarlanabilir.

$\mathrm{Bu}$ araştırmadan elde edilen sonuçlarda belirtildiği üzere, öğretmenlerin çocuk cinsel istismarının bildirimine yönelik tutumlarını olumsuz etkilediği tespit edilen etmenlerin daha net ortaya konulması açısından nitel çalışmalarla bu sonuçlar desteklenebilir.

$\mathrm{Bu}$ araştırmadan elde edilen sonuçlar temel alınarak öğretmenlerin, bildirim sürecinde olumsuz etkilendiği etmenleri ortadan kaldırmak adına ulusal eğitim politikaları tasarlanarak görünür kılınabilir ve tüm öğretmenlerin erişebileceği yüz yüze ya da uzaktan eğitimlerle bilgi ve deneyimleri artırılabilir.

\section{Kaynakça}

Abrahams, N., Casey, K., and Daro, D. (1992). Teachers' knowledge, attitudes, and beliefs about child abuse and its prevention. Child Abuse \& Neglect, 16(2), 229238. https:// doi.org/10.1016/0145-2134(92)90030-U

Akgül, E. (2015). Okul öncesi eğitim kurumlarında çalışan personelin cinsel istismar bildirim durumları. (Yayınlanmamış Yüksek Lisans Tezi). Hacettepe Üniversitesi Eğitim Bilimleri Enstitüsü. Ankara.

Aksel, Ş. ve Yılmaz Irmak, T. (2015). Çocuk Cinsel İstismarı Konusunda Öğretmenlerin Bilgi ve Deneyimleri. Ege Eğitim Dergisi 16(2), 373-391. https:/ / doi.org/10.12984/eed.60194

Alaggia, R., Collin-Vezina, D., and Lateef, R. (2017). Facilitators and barriers to child sexual abuse (CSA) disclosures: A research update (2000-2016). Trauma, Violence and Abuse,1-24. https:// doi.org/10.1177/1524838017697312.

American Psychological Association (2014). Child sexual abuse: what parents should know overview. https:/ / www.apa.org/pi/families/resources/understandingchild-abuse Erişim Tarihi: 06.06.2020

Ayeş Aslan, E. ve Çelik, İ. (2020). Okul öncesi öğretmenlerinin çocuk istismarına yönelik farkındalık düzeyinin incelenmesi. Akdeniz Üniversitesi Ĕ̆itim Fakültesi Dergisi, 3(1), 40-56 . https:// doi.org/10.21565/ozelegitimdergisi.799776

Ayraler-Taner, H., Çetin, F. H., Işık, Y., ve İşeri, E. (2015). Cinsel istismara uğrayan çocuk ve ergenlerde psikopatoloji ve ilişkili risk etmenleri. Anadolu Psikiyatri Dergisi, 16(4), 294-300. https:/ / doi.org/10.5455/ apd.162514

Aral, N. ve Gürsoy, F. (2001). Çocuk hakları çerçevesinde çocuk ihmal ve istismarı. Milli Ĕ̆itim Dergisi, 151(1), 4-5.

Baginsky, M. (2003). Newly qualified teachers and child protection: A survey of their views, training and experiences. Child Abuse Review, 12(2), 119-127. https:/ / doi.org/10.1002/car.783

Bakır, E. ve Kapucu, S. (2017). Çocuk ihmali ve istismarının Türkiye'de yapılan araştırmalara yansıması: bir literatür incelemesi. Hacettepe Üniversitesi Hemşirelik Fakültesi Dergisi, 4(2), 13-24.

Beck, K.A., Ogloff, J.R.P., and Corbishley, A. (1994). Knowledge, compliance, and attitudes of teachers towards mandatory child abuse reporting in British Columbia. Canadian Journal of Education, 19(1), 15-29. https:/ / doi.org/10.2307/1495304 
Behun, R.J., Cerrito, J.A., Delmonico, D.L., and Kolbert, J.B. (2019). The influence of personal and professional characteristics on school counselors' recognition and reporting of child sexual abuse. Journal of School Counseling, 17(13), 1-34.

Borg, K., Snowdon, C., and Hodes, D. (2014). Child sexual abuse: Recognition and response when there is a suspicion or allegation. Pediatrics and Child Health, 24(12), 536-543. https:/ / doi.org/10.1016/j.paed.2014.07.012

Can Yaşar, M., İnal Kızıltepe, G., ve Kandır, A. (2014). Öğretmen adaylarının çocuklardaki fiziksel istismar belirtilerine ilişkin farkındalıkları. Kuramsal Eğitimbilim Dergisi, 7(3), 286-303. https:// doi.org/10.5578/keg.7295

Can Yaşar, M., Şenol, F.B., ve Akyol, T. (2015). Öğretmen adaylarının çocuğa yönelik cinsel istismar tutumlarının incelenmesi. Hacettepe University Faculty of Health and Sciences Journal, 1(2), 228-241.

Can Yaşar, M., Karaca, N.H., ve Kaya, Ü.Ü. (2018). Çocuk cinsel istismarının bildirimine yönelik öğretmen tutum ölçeği'nin Türkçe' ye uyarlama çalışması. PESA International Journal of Social Studies, 4(2), 265-273.

Can Yaşar, M., Erbasan, Ö., Akçeşme, B., Korkmaz, Ç., ve Gedik, H. (2018). Sınıf öğretmenlerinin çocuğa yönelik cinsel istismar tutumlarının incelenmesi. The Journal of Academic Social Science Studies, 73, 1-16. https://doi.org/10.9761/JASSS7927

Choo, W.Y., Walsh, K., Marret, M.J., Chinna, K., and Tey, N.P. (2013). Are malaysian teachers ready to assume the duties of reporting child abuse and neglect? Wiley Online Library, 2, 93-107. https:/ / doi.org/10.1002/car.2241

Cohen, L., Manion, L., and Morrison, K. (2000). Research methods in education (5th ed). London New York: Routledge Falmer. https:/ / doi.org/10.4324/9780203224342_chapter_1

Collin-Vezina, D., De La Sablonniere-Griffin, M., Palmer, A.M., and Milne, L. (2015). A preliminary mapping of individual, relationsal, and social factors that impeded disclosure ofchildhood sexual abuse. Child Abuse E Neglect, 43, 123134. doi: 10.1016/j.chiabu.2015.03.010.

Crenshaw WB, Lichtenberg JW, and Bartell PA. (1993). Mental health providers and child sexual abuse: a multivariate analysis of the decision to report. J Child Sex Abuse,(2), 19-42. https:/ / doi.org/10.1300/J070v02n04_02

Crenshaw, W.B., Crenshaw, L.M., and Lichtenberg, J.W. (1995). When educators confront child abuse: An analysis of the decision to report. Child Abuse $\mathcal{E}$ Neglect, 19(9), 1095-1113. https:/ / doi.org/10.1016/0145-2134(95)00071-F

Crosson-Tower, C. (2003). The role of educators in preventing and responding to child abuse and neglect. Child Abuse and Neglect User Manual Series. U.S.

Department of Health and Human Services. Web: http://www.childwelfare.gov/pubs/usermanuals/educator/educator.pdf. Erişim Tarihi: 26 Mart 2017.

Çapri, B. and Demiröz, Z. (2016). Investigation of teachers' attitudes toward reporting child sexual abuse according to gender roles. The Global E-Learning Journal, 5(2), 1-13.

Çopur, A., Balc1, E., ve Günay, O. (2019). Sağlık meslek lisesinde görev yapan öğretmenlerin çocuk ihmal ve istismarı konusundaki bilgi düzeylerinin 
belirlenmesi. Uluslararası Sosyal Araştırmalar Dergisi, 12(63), 808-813. https://doi.org/10.17719/jisr.2019.3277

Draper, B., Pfaff, J.J., Pirkis, J., Snowdon, J., Lautenschlager, N.T., Ian, W., and Almeida, O.P. (2008). Long-term effects of childhood abuse on the quality of life and health of older people: results from the depression and early prevention of suicide in general practice project. American Geriatrics Society, 56, 262-271. https:/ / doi.org/10.1111/j.1532-5415.2007.01537.x

Esin, İ.S., Şener, M.T., Dursun, O., Aş1khasanoğlu, E.O., and Secer, İ. (2020). The challenges faced by school counsellors in reporting sexual abuse. European Journal of Education Studies, 6(10), 245-257.

Farrell, A. and Walsh, K. (2010). Working together for Toby: Early childhood student teachers engaging in collaborative problem-based learning around child abuse and neglect. Australasian Journal of Early Childhood, 35(4), 53-62. https:/ / doi.org/10.1177/183693911003500407

Feng, J.Y., Huang, T.Y., and Wang, C.J. (2010). Kindergarten teachers' experience with reporting child abuse in Taiwan. Child Abuse \& Neglect, 34(2), 124-128. https:/ / doi.org/10.1016/j.chiabu.2009.05.007

Gilligan, C. (1982). In a different voice: psychological theory and women's development. England: Harvard University Press.

Gönültaş, M. B. (2016). Çocuklara yönelik cinsel istismar suçlarında mağdur bildirimlerinin önemi. Akademik Sosyal Araştırmalar Dergisi, 4(23), 274-289. https:/ / doi.org/10.16992/ ASOS.1083

Haileye, A. (2013). Psychopathological correlates of child sexual abuse: The case of female students in jimma zone: south west Ethiopa. Ethiop Journal of Science, 23(1), 32-38.

Haj-Yahia, M.M., and Attar-Schwartz, S. (2008). Attitudes of palestinian pre-school teachers from israel towards reporting of suspected cases of child abuse and neglect. Child \& Family Social Work 13(4), 378-390.

https:/ / doi.org/10.1111/j.1365-2206.2008.00562.x

Hawkins, R. and McCallum, C. (2001). Effects of mandatory notification training on the tendency to report hypothetical cases of child abuse and neglect. Child Abuse Review, 10, 301-322. https:/ / doi.org/10.1002/car.699

Hinson, J. and Fossey, R. (2000). Child abuse: What teachers in the 90s know, think and do. Journal of Education for Students Placed at Risk, 5(3), 251-266. https://doi.org/10.1207/S15327671ESPR0503_4

Hornor, G. (2010). Child sexual abuse: Consequences and implications. Journal of Pediatric Health Care, 24(6), 358-364.

https:/ / doi.org/10.1016/j.pedhc.2009.07.003

Humphries, R. L., Debowska, A., Boduszek, D., and Mattison, M.L. (2016). Gender differences in psychosocial predictors of attitudes toward reporting child sexual abuse in the United Kingdom, Journal of Child Sexual Abuse, 25(3), 293-309. doi:10.1080/10538712.2016.1133752

Koç, S., Ekşi, H., and Türk, T. (2020). Psychometric properties of teachers' attitudes toward reporting Child Sexual Abuse Scale: Turkish form. Elementary Education Online, 19(1), 173-182. https:/ / doi.org/10.17051/ilkonline.2020.649372

Karasar, N. (2010). Bilimsel araştırma yöntemi. Ankara: Nobel Yayıncılık. 
Kenny, M.C. (2001). Child abuse reporting: Teachers' perceived deterrents. Child Abuse E Neglect, 25(1), 81-92. https:/ / doi.org/10.1016/S0145-2134(00)00218-0

Kenny, M.C. (2004). Teachers' attitudes toward and knowledge of child maltreatment. Child Abuse \& Neglect, 28(12), 1311-1319.

Kesner JE, \& Robinson M. (2002). Teachers as mandated reporters of child maltreatment, s. comparison with legal, medical, and social services reporters. Children and Schools, 24(4), 222-231.https:/ / doi.org/10.1016/j.chiabu.2004.06.010

King, G., Reece, R., Bendel, R., and Patel, V. (1998). The effects of sociodemographic variables, training, and attitudes on the lifetime reporting practices of mandated reporters. Child Maltreatment, 3, 276-283. doi:10.1177/1077559598003003007

Koçak, U. ve Alpaslan, A. H. (2015). Cinsel istismara uğrayan çocuk ve ergenlerin sosyodemografik özellikleri ve ruhsal değerlendirmesi. Adli Tıp Bülteni, 20(1), 27-33. https:/ / doi.org/10.17986/blm.2015110915

Kohlberg, L. (1973). The claim to moral adequacy of a highest stage of moral judgment. The Journal of Philosophy, 70(18), 630-646.

https:/ / doi.org/10.2307/2025030

Lahtinen, H.M., Laitila, A., Korkman, J., and Ellonen, N. (2017). Children's disclosures of sexual abuse in a population-based sample. Child Abuse E Neglect, 76, 84-94. https://doi.org/10.1016/j.chiabu.2017.10.011

Laraque, D., DeMatta, A., and Low, C. (2006). Forensic child abuse evaluation, $M t$. Sinai J. Med., 73(8), 1138-1147.

Lynn, K. (2008). Evaluating potential obstacles to mandated reporting of child abuse and neglect by educators in a suburban public school district (Doctoral dissertation). Available from ProQuest Dissertations and Theses database. (UMI No. 3370298)

Marks, S., Lamb, R., and Tzioumi, D. (2009). Do no more harm: the psychological stress of the medical examination for alleged child sexual abuse, J. Paediatr Child Health, 45(3), 125-132. https:/ / doi.org/10.1111/j.1440-1754.2008.01443.x

McElvaney, R., Moore, K., O’Reilly, K., Turner R., Walsh, B., and Guerin, S. (2020). Child sexual abuse disclosures: Does age make a difference? Child Abuse $\mathcal{E}$ Neglect, 99, 1-10. doi: 10.1016/j.chiabu.2019.104121

McKee, B.E. and Dillenburger, K. (2009). Child abuse and neglect: training needs of student teachers. International Journal of Educational Research, 48(5), 320-330. https:/ / doi.org/10.1016/j.ijer.2010.03.002

Morrison, S.E., Bruce, C., and Wilson, S. (2018). Children's disclosure of sexual abuse: A systematic review of qualitative research exploring barriers and facilitators. Journal of Child Sexual Abuse, 27(2), 176-194. doi: 10.1080/10538712.2018.1425943.

Murali, P. and Prabhakar, M. (2018). Mantle of forensics in child sexual abuse. Journal of Forensic Dental Sciences, 10(2), 71-74. https://doi.org/10.4103/jfo.jfds_17_18

Noble, J., Hartwig, E., and Shwayder, T. (2020). Cutaneous manifestations of physical and sexual child abuse. Indian Journal of Paedeatric Dermatology, 21(1), 1-10. https:/ / doi.org/10.4103/ijpd.IJPD_62_19

Olive, M.F., Collins, C., and Levitt, P. (2007). Child abuse and stress disorders. New York: Chelsea House Publications.

O'Toole, R., Webster, S.W., O'Toole, A.W., and Lucal, B. (1999). Teachers' recognition and reporting of child abuse: A factorial survey. Child Abuse E Neglect, 23(11), 1083-1101. https://doi.org/10.1016/S0145-2134(99)00074-5 
Resmi Gazete (2014).

https:/ / www.resmigazete.gov.tr/eskiler/2004/10/20041012.htm Erişim Tarihi: 29.04.2020.

Ross, A.H. and Juarez, C.A. (2014). A brief history of fatal child maltreatment and neglect. Forensic Sci Med Pathol, 10, 413- 422.

Sarıbaş A. (2013). Okul öncesi öğretmenlerinin çocuk istismarına yönelik farkındalıklarının belirlenmesi. (Yayımlanmamış Yüksek Lisans Tezi). Çanakkale Onsekiz Mart Üniversitesi Eğitim Bilimleri Enstitüsü, Çanakkale.

Seth, R. and Srivastava, R.N. (2017). Child Sexual Abuse: Management and prevention, and protection of children from sexual offences (POCSO). Act, Indian Pediatrics, 54, 949. https:/ / doi.org/10.1007/s13312-017-1189-9

Shavelson, R. J. (1996). Statistical reasoning for the behavioral sciences (3rd ed.). Boston: Allyn and Bacon.

Swea, J.T., Gordana, B.F., and Dragana, M. (2013). The consequences of childhood abuse. Pediatrics Today, 9(1), 24-35. https://doi.org/10.5457/p2005-114.58

Şahin, F. ve Beyazova, U. (2001). Çocuğun şiddetten korunma hakk1. Milli Ĕ̆gitim Dergisi, 151.

http://dhgm.meb.gov.tr/yayimlar/dergiler/milli_egitim_dergisi/151/sahin_b eyazova.htm Erişim Tarihi: 02.06.2020

Şahin, F. (2006). Çocuk İstismarının tanıtımı, epidemiyolojisi ve multidisipliner yaklaşımın önemi. Çocuk istismarı ve İhmaline Multidisipliner Yaklaşım. Ankara: Ankara Üniversitesi basımevi, 5-8.

Tugay, D. (2008). Öğretmenlerin çocuk istismarı ve ihmaline yönelik farkındalık düzeyleri. (Yayımlanmamış Yüksek Lisans Tezi). Marmara Üniversitesi Sağlık Bilimleri Enstitüsü, İstanbul.

Ulum, Ö. (2020). Pre-Service EFL Teachers' attitudes towards reporting child sexual abuse (CSA): A sample of Turkey. OPUS Uluslararası Toplum Araştırmaları Dergisi, 15(23), 1601-1613. doi: 10.26466/opus.654893

Walsh, K. and Farrell, A. (2008). Identifying and evaluating teachers' knowledge in relation to child abuse and neglect: A qualitative study with Australian early childhood teachers. Teaching and Teacher Education, 24, 585-600. https:/ / doi.org/10.1016/j.tate.2007.07.003

Walsh, K., Bridgstock, R., Farrell, A., Rassafiani, M., and Schweitzer, R. (2008). Case teacher and school characteristics influencing teachers' detection and reporting of child physical abuse and neglect: Results from an Australian survey. Child Abuse E Neglect, 32(10), 983-993. https:/ / doi.org/10.1016/j.chiabu.2008.03.002

Walsh, K., Rassafiani, M., Mathews, B., Farrell, A., and Butler, D. (2010). Teachers' attitudes toward reporting child sexual abuse: problems with existing research leading to new scale development. Journal of child sexual abuse. 19(3), 310-36. https:/ / doi.org/10.1080/10538711003781392

Walsh, K., Mathews, B., Rassafiani, M., Farrell, A., and Butler, D. (2012). Understanding teachers' reporting of child sexual abuse: Measurement methods matter. Children and Youth Services Review, 34(9), 1937-1946. https://doi.org/10.1016/j.childyouth.2012.06.004

Walsh, K., Mathews, B., Rassafiani, M., Farrell, A., and Butler, D. (2013). Elementary teachers' knowledge of legislative and policy duties for reporting child sexual 
abuse. The Elementary School Journal, 114(2), 178-199.

https://doi.org/10.1086/671934

Wamser-Nanney, R., and Sager, J. C. (2018). Predictors of maternal support following children's sexual abuse disclosures.Child Abuse \& Neglect, 81, 39-47. doi:10.1016/j.chiabu.2018.04.016.R.

Wamser-Nanney, R., and Campbell, C.L. (2020). Children's coping following sexual abuse: the roles of abuse characteristics, abuse stress, and maternal support. $J$ Child Fam Stud, 29, 514-525. doi:10.1007/s10826-019-01540-3

Wurtele, S.K. and Schmitt, A. (1992). Child care workers' knowledge about reporting suspected child sexual abuse. Child Abuse E Neglect, 16(3), 385-390. https:/ / doi.org/10.1016/0145-2134(92)90047-U

WHO/World Health Organization (2017). Responding to children who have been sexually abused. WHO Clinical Guidelines. Geneva: World Health Organization.

Yilmaz, Y., ve Cenkseven Önder, F. (2020). Öğretmenlerin cinsel istismar durumlarını bildirme tutumları ölçeği: türkçeye uyarlama, geçerlik ve güvenirlik çalışması. International Journal of Innovative Approaches in Education, 4(1), 1-11. doi: 10.29329/ijiape.2020.239.1

Yulaf, Y., ve Gümüştaş, FÖ. (2013). Çocuk ve ergenlerde cinsel istismarın psikiyatrik sonuçlarını etkileyen faktörler. Klinik Psikiyatri Dergisi, 16(4), 152-160.

Zellman, G. (1990). Linking schools and social services: the case of child abuse reporting. Educational Evaluation and Policy Analysis, 12(1), 41-55.

https:/ / doi.org/10.3102/01623737012001041

\section{Summary}

\section{Introduction}

Child sexual abuse is a universal reality that affects children's lives physically, psychologically, socially and developmentally, and is the gravest violation of children's rights. Teachers working in the field of early childhood (preschool and classroom education teachers) are in the first place in terms of effectiveness in creating social awareness with a holistic approach. For this reason, it is vital for the integrity of the child that preschool and classroom teachers have the necessary knowledge and skills to protect children from sexual abuse and prevent sexual abuse. This study was conducted to investigate the factors that affect teachers' attitudes towards child sexual abuse reporting.

\section{Method}

Since the study aimed to examine the factors affecting teachers' attitudes towards reporting child sexual abuse, the relational research design was used. The study group of the research included 213 elementary and 207 preschool teachers working at kindergartens and elementary schools affiliated to the Directorate of National Education in Afyonkarahisar city center during 2019-2020 academic year. In the research, "General Information Form" was used to collect the personal information of teachers and "Teacher Reporting Attitude Scale for Child Sexual Abuse" (Walsh, Rassafiani, Mathews, Farrel \& Butler, 2010) was used to determine teachers' attitudes towards reporting sexual abuse. The personal information of the teachers included in 
the study in the general information form were given in frequency and percentage distributions. In the analysis of the data obtained from the "Teacher Reporting Attitude Scale for Child Sexual Abuse"; Manny Whitney U Test was used for the variables of gender, graduated program, whether they have received any education related to child protection law and child sexual abuse, professional awareness of the responsibility of reporting possible child neglect and abuse regarding national education policies while Kruskall Wallis H Test was used for professional seniority.

\section{Results}

As a result of the data obtained from the "Teacher Reporting Attitude Scale for Child Sexual Abuse", male teachers reported that they felt more social anxiety than female teachers during the reporting process. Female teachers also stated that they would display a stronger will of determination than male teachers with their average scores. Statistically significant, it was concluded that classroom teachers felt more social anxiety during the reporting process than preschool teachers. In addition, it was determined that preschool teachers felt more ethical responsibilities in the reporting process than classroom teachers and followed a more decisive path in the process. It has been determined that senior preschool teachers feel more personal anxiety than their newly graduated or experienced colleagues up to 15 years. It has been determined that education has a positive effect on ethics and commitment and the social anxiety of the teachers who do not receive education is higher. Considering these results and the average scores of the teachers, it is possible to conclude that the attitudes of the educated teachers towards reporting child sexual abuse are positively affected.

\section{Pedagogical Implications}

In order to contribute more to the literature, this study can be repeated with different variables with a wider participation on different branch teachers in terms of factors affecting the reporting of child sexual abuse. As stated in the results obtained from this study, these results can be supported with qualitative studies in order to reveal more clearly the factors that are found to have a negative effect on teachers' attitudes towards reporting child sexual abuse. Based on the results obtained from this research, national education policies can be designed and made visible to eliminate the factors that teachers are affected negatively during the reporting process, and their knowledge and experience can be increased by face-to-face or distance education that all teachers can access.

\section{Authors' Biodata / Yazar Bilgileri}

Münevver CAN YAŞAR Ankara Üniversitesi Fen Bilimleri Enstitüsü Çocuk Gelişimi ve Eğitimi Anabilim Dalı'nda 2009 yılında doktorasını tamamlamış ve öğretim üyesi olarak hizmet verdiği Afyon Kocatepe Üniversitesi'nde sırasıyla yardımcı doçent doktor ve doçent doktor ünvanlarını almıştır. Halen İzmir Demokrasi Üniversitesi Okul Öncesi Eğitimi anabilim dalında öğretim üyesidir.

Münevver Can Yaşar She completed her doctorate at Ankara University, Institute of Science, Department of Child Development and Education in 2009 and received the 
titles of assistant professor and associate professor respectively at Afyon Kocatepe University where she served as a faculty member. Currently, she is a lecturer in Izmir Democracy University, Department of Preschool Education.

Ümit ÜNSAL KAYA Orta Doğu Teknik Üniversitesi İngilizce Öğretmenliği bölümünden mezun olduktan sonra sınıf eğitimi alanında yüksek lisansını tamamlamış ve Afyon Kocatepe Üniversitesi Okul Öncesi Eğitimi anabilim dalında misafir öğretim üyesi olarak hizmet verirken aynı alanda doktora çalışmalarını yürütmektedir.

Ümit Ünsal Kaya After graduating from the Department of English Language Teaching at Middle East Technical University, he completed his master's degree in elementary education and while serving as a visiting lecturer in the Department of Preschool Education at Afyon Kocatepe University.

Nezahat HAMIDEN KARACA Ankara Üniversitesi Fen Bilimleri Enstitüsü Çocuk Gelişimi ve Eğitimi Anabilim Dalı'nda doktorasını tamamlamış ve öğretim üyesi olarak hizmet verdiği Afyon Kocatepe Üniversitesi'nde yardımcı doçent doktor ünvanını almıştır.

Nezahat Hamiden Karaca Having completed her doctorate at Ankara University, Institute of Science, Department of Child Development and Education, she received the title of assistant professor at Afyon Kocatepe University, Department of Preschool Education where she still serves as a faculty member. 